\title{
Arbeid med klart språk i norske lover
}

\author{
Aud Anna Senje
}

\section{Hvorfor er det viktig å arbeide med språket i lover og forskrifter?}

Det er ikke noe mål at absolutt alle lovtekster skal forstås av absolutt alle. Men viktige lovtekster som angår mange, bør få en språklig utforming som gjør at de lett kan forstås. Lover og forskrifter påvirker beslutninger på alle nivåer i samfunnet, og de setter standard for andre tekster i det offentlige. Hvis lovspråket er innadvendt, komplisert og omstendelig, kan det føre til at rettigheter og plikter ikke blir godt nok belyst, og det er et demokratisk problem.

Fornærmedes navn skal ikke oppgis i berammingslisten med mindre dette finnes ubetenkelig.

Det kan gis oppfriskning mot oversittelse av søksmålsfristen.

Enhver skal på begjæring som fremsettes for påtalemyndigheten, gis underretning om hworvidt det har vært iverksatt tiltak mot vedkommende etter dette kapitlet.

Til skade for mistenkte kan retten bare bygge på et faktisk grunnlag som er påberopt.

Ved manglende samarbeidsvilje fra gjenlevende vil rettens avgjorelse også kunne brukes av arvingene for å kreve innsyn.

Figur 1. Språket i mange lover er mer komplisert enn det faglige innholdet krever. I flere tilfeller er det formuleringen, ikke regelen, som gjør det vanskelig å forstå teksten. Disse formuleringene er hentet fra norske lover og lovutkast.

Uklart formulerte regler er vanskeligere å håndheve, så uklart språk i regelverk kan gjøre forvaltningen mindre effektiv. Klarere språk i regelverket vil føre til klarere forvaltningsspråk på de områdene der reglene gjelder, og dermed kan forvaltningen spare både tid og penger. Klart formulerte regler er dessuten lettere å digitalisere. 


\section{Hva skjer med lovspråk i Norge?}

Undersøkelsen Kan lovspråk temmes?, som Difi (Direktoratet for forvaltning og IKT, fra 2020: Digitaliseringsdirektoratet) fikk utført blant statlige saksbehandlere i 2013, viser at det ikke finnes faste rutiner for språklig kvalitetssikring underveis $i$ arbeidet med lover og forskrifter, og at språket i tekstene heller ikke blir gjennomgått til slutt. Respondentene i undersøkelsen oppgir tidspress og innarbeidet skrivekultur som noen av de viktigste årsakene til at språk ikke blir prioritert når lover og forskrifter skal utarbeides.

De siste årene har interessen for språket i lover og forskrifter økt. Krav om klart språk og ryddig struktur inngår i mandatet til stadig flere utvalg som skal skrive nye eller revidere eksisterende lover. Når målet er at lovene skal være oversiktlige og brukervennlige, kommer man ikke utenom arbeid med språket, og da trenger man språkfaglig bistand. Slik bistand kan gis både av Språkrådet og av private aktører. Flere viktige norske lover er revidert eller under revisjon, og flere lovutvalg og departementer har fått språkfaglig bistand $\mathrm{i}$ arbeidet.

Her er noen eksempler på språklige krav i mandater for lovutvalg:

Utvalgets lovforslag skal ha god struktur og være skrevet i et godt og klart språk slik at forslaget også forstås av de som ikke er jurister. (Mandat for universitetsog høyskolelovutvalget, 2018)

Loven skal utformes i et klart og godt språk og være informativ og brukervennlig for alle grupper i samfunnet. (Mandat for barnelovutvalget, 2018)

Loven skal utformes i et klart og godt språk. (Mandat for opplæringslovutvalget, 2017)

Et vesentlig siktemål med lovarbeidet er å oppnå brukervennlige regler.

Lovforslaget bør derfor ha god systematikk og et enkelt og klart språk. (Mandat for forvaltningslovutvalget, 2015)

Loven skal utformes i et klart og godt språk og være informativ og brukervennlig, også for ikke-jurister. (Mandat for straffeprosesslovutvalget, 2014)

I 2011 etablerte Kommunal- og moderniseringsdepartementet et prosjekt som fikk navnet «Klart lovspråk». Prosjektet var en del av en større satsing på klart språk i offentlig sektor og ble ledet av Direktoratet for forvaltning og IKT (i dag: Digitaliseringsdirektoratet). Formålet med prosjektet var å få mer kunnskap om de språklige utfordringene i regelverket og å sette i gang tiltak for å gjøre språket i regelverk klarere og bedre. Blant tiltakene i prosjektet var kurs, undersøkelser, seminarer og omfattende språklig og strukturell kvalitetssikring av tre utvalgte lovtekster. Målet med kvalitetssikringen var ikke bare å forbedre de aktuelle lovtekstene, men også å utvikle en metode som skulle kunne brukes $\mathrm{i}$ arbeid med andre viktige lover. Språkrådet og 
Justis- og beredskapsdepartementets lovavdeling var blant deltakerne i prosjektet «Klart lovspråk».

Prosjektet ble avsluttet i 2019, men arbeidet med klart språk i regelverk blir videreført innenfor andre rammer. Kommunal- og moderniseringsdepartementet og Universitetet i Oslo arbeider med lovspråk på overordnet nivå. Juridisk fakultet ved Universitetet i Oslo har satt i gang prosjektet «Klarspråk i juridisk forskning og undervisning», som skal bidra til at lover og andre juridiske tekster blir lettere å forstå.

\section{Språkrådets rolle i lovarbeidet}

Språkrådet har lenge hatt en sentral rolle i arbeidet med klart språk i offentlig sektor, og språklig kvalitetssikring av lovtekster er en viktig del av oppdraget vårt. Med språklig kvalitetssikring mener vi grundig gjennomgang og redigering av teksten på alle nivåer - fra tegnsetting og setningsbygning til overskrifter, logisk sammenheng og avsnittsplassering. Flere lovutvalg og departementer har fått språkfaglig bistand fra oss. Dessuten har vi holdt mange kurs om godt språk i regelverk.

Språkrådet har arbeidet med lovtekster både på egen hånd og innenfor prosjektet «Klart lovspråk». Vi har deltatt i arbeidet med blant annet disse lovene:

- Grunnloven/Grunnlova

- ny adopsjonslov

- ny forsvarslov med forskrifter

- ny opplæringslov

- ny kommunelov

- ny sikkerhetslov

- ny havne- og farvannslov

- ny barnevernslov

- ny barnelov

- ny forvaltningslov

- ny lov om tros- og livssynssamfunn

- ny valglov

- ny lov om rettshjelp

I arbeidet med mange av disse lovtekstene har vi brukt en tverrfaglig metode som gjerne kalles skriveverksted (se omtalen nedenfor).

Språklig kvalitetssikring av lovtekster er ikke obligatorisk i Norge, og som nevnt finnes det ikke faste rutiner for slikt. De som skriver lovene, avgjør selv om de vil trekke inn språkfaglig ekspertise, enten fra Språkrådet eller fra private aktører. Språkrådet har i liten grad behøvd å markedsføre sitt tilbud om bistand. Flere lovutvalg og departementer har på eget initiativ tatt kontakt med oss. Når et lovutvalg tar kontakt, er det som oftest fordi utvalgets mandat inneholder eksplisitte krav til språket i den loven som skal skrives eller 
revideres. Språkrådet har bistått både lovutvalg (før høringsrunden) og departementer (etter høringsrunden). Siden vi har begrensede ressurser, prioriterer vi lover framfor forskrifter.

\section{Skriveverkstedmetoden}

Den tverrfaglige skriveverkstedmetoden er utviklet gjennom praksis, og den er utførlig beskrevet på nettstedet klarspråk.no og i Difis metodehefte Råd og tips til dere som skal arrangere skriveverksteder - en arbeidsmetode som setter tverrfaglig samarbeid i system (Difi 2016a). Flere norske statsorganer har gjort bruk av metoden. Et eksempel er Barne- og familiedepartementet, som lenge har brukt metoden i sitt interne arbeid med tekster.

Skriveverkstedmetoden går ut på at jurister, filologer og andre fagpersoner arbeider med et tekstutkast og diskuterer seg fram til løsninger som sikrer både juridisk presisjon og språklig kvalitet.

Filologenes oppgave er å påpeke uklarheter og hindringer i tekstene og foreslå endringer som kan lette forståelsen. Deltakerne i skriveverkstedet diskuterer teksten i flere omganger og blir enige om hvilke endringer som skal gjøres. Dette arbeidet er som en forhandling, der målet er å finne løsninger som både er forståelige, språklig gode og faglig holdbare.

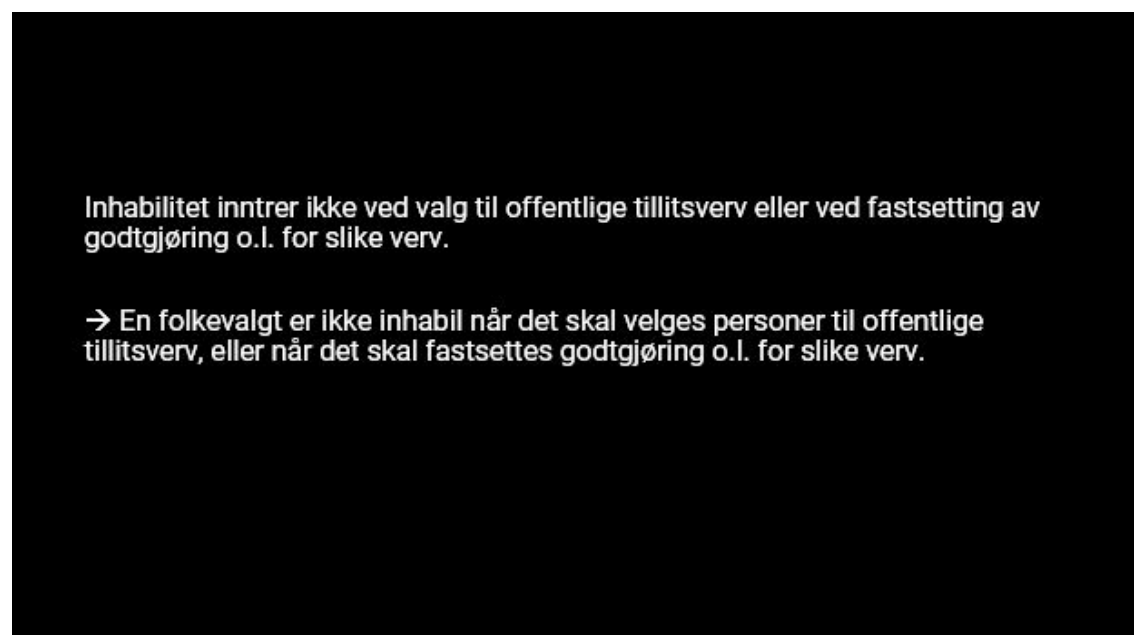

Figur 2. Eksempel på formulering som ble endret i et skriveverksted.

Arbeidsgangen er slik:

- Departementet/lovutvalget sender teksten til filologene (Språkrådet) senest en uke før møtet.

- Filologene sender begrunnede skriftlige innspill til teksten.

- Departementet/lovutvalget vurderer innspillene.

- Innspillene blir gjennomgått i tverrfaglige arbeidsgruppemøter. Forslag blir drøftet, eventuelle misforståelser blir oppklart, og 
nødvendige språklige og strukturelle endringer blir innarbeidet $\mathrm{i}$ teksten.

Skriveverkstedmetoden er ressurskrevende, men svært nyttig og lærerik for alle parter. Departementer og lovutvalg som bestiller språklig kvalitetssikring av lovteksten, kan lære noe om hvordan utenforstående oppfatter teksten, og denne lærdommen kan de ta med seg videre. I rapporten Klart språk gir resultater (Difi 2016b) omtaler Forsvarsdepartementet sine erfaringer med metoden, som ble brukt $\mathrm{i}$ arbeidet med ny forsvarslov.

Deltakelse i skriveverksted kan tilføre lovskrivere nyttig skrivekompetanse som kan brukes i annet lovarbeid, men slik kompetanse vil ikke fullt ut kunne erstatte språkfaglig eksperthjelp.

\section{Erfaringer fra arbeidet med lovtekster}

Språkrådet har erfart at de fleste skribenter er lydhøre og velvillig innstilt til språklige endringsforslag. I de tverrfaglige arbeidsmøtene er det stor takhøyde, nyttige diskusjoner og rom for saklig uenighet. Stort sett kommer vi fram til gode løsninger. Brukertesting av flere lovtekster (Opinion AS for Difi 2015a og 2015b) har vist at denne arbeidsformen gir lovtekster som er klarere, bedre strukturert og mer forståelige. Tilbakemeldingene fra brukerne er gjennomgående positive. Difi, som ledet prosjektet «Klart lovspråk», har evaluert selve arbeidet med de tre utvalgte lovtekstene (se omtalen ovenfor) gjennom en spørreundersøkelse blant deltakerne i skriveverksted. Undersøkelsen ble gjennomført i to omganger (2014 og 2016) fordi arbeidet strakte seg over flere år, og fordi lovtekstene ble ferdigstilt på ulike tidspunkter. I 2014-undersøkelsen sier 82 prosent av respondentene seg helt enig eller delvis enig i påstanden om at arbeidsformen som er brukt, vil gjøre språket og strukturen i loven enklere og bedre enn det ellers ville ha blitt. 82 prosent er helt enige eller delvis enige $\mathrm{i}$ påstanden om at arbeidet gir dem verdifull kompetanse som de kan bruke i annet lovarbeid. I 2016-undersøkelsen sier 92 prosent av respondentene seg helt eller delvis enig i den første og den andre påstanden. 83 prosent er helt enige eller delvis enige $\mathrm{i}$ påstanden om at arbeidet gir dem verdifull kompetanse som de kan bruke $i$ annet lovarbeid.

Difi hadde opprinnelig til hensikt å finne ut om de utvalgte lovtekstene som ble revidert innenfor prosjektet, fungerte bedre enn de opprinnelige tekstene, for eksempel ved å undersøke om de nye lovtekstene førte til færre henvendelser og unødige klager. Men på grunn av omorganisering ble Difis arbeid med klart lovspråk i liten grad fulgt opp etter 2018. Det er ikke gjennomført nye undersøkelser som viser om arbeidet med lovtekster de siste årene har gitt konkrete resultater.

I skriveverkstedene får Språkrådet langt på vei gjennomslag for endringsforslagene, men vi kan aldri regne med at sluttresultatet blir «hundre prosent». Likevel blir tekstene språklig sett langt bedre enn de ville ha blitt om vi ikke hadde gjennomgått og kommentert dem. 
Før skriveverkstedmetoden ble tatt i bruk (rundt 2014), ga Språkrådet bistand ved å sende skriftlige innspill til lovtekster uten å få noen klare tilbakemeldinger. Det fantes ikke noen retningslinjer for arbeidsmåten. I dag setter Språkrådet som vilkår for bistanden at vi skal få delta i tverrfaglige møter og drøfte og utdype innspillene våre. Dette vilkåret blir stort sett akseptert av oppdragsgiverne. Bruken av skriveverksted som metode representerer et stort framskritt, faktisk et veiskille, $\mathrm{i}$ arbeidet med lovtekster. Men enkelte utfordringer gjenstår.

\section{Noen utfordringer i arbeidet med lovtekster}

I skriveverkstedene diskuterer kvalifiserte fagfolk seg fram til endringer som gjør tekstene lettere tilgjengelige, og de bruker mye tid og krefter på å lage språklig gode og juridisk holdbare formuleringer. Men i sluttfasen hender det at personer som ikke har deltatt i tekstarbeidet (og som derfor ikke vet hvilke vurderinger og diskusjoner som ligger bak endringene), griper inn og reverserer endringene. Formuleringer som er vanskelige å forstå for uinnvidde, forplanter seg dermed videre til andre lover, forskrifter og andre forvaltningstekster.

I arbeidet med språket i en lovtekst avdekkes nesten alltid svakheter ved selve innholdet. Da må det være tid og rom for nødvendige justeringer. Tidspress (ofte fra politisk ledelse) kan føre til at den siste kvalitetssikringen av lovteksten blir ufullstendig, eller at den ikke blir gjennomført. Dermed kan svakheter i teksten bli oversett.

\section{Retningslinjer og verktøy for utforming av regelverk}

Det finnes offentlige styringsdokumenter som sier noe allment om utforming av regelverk. Et sentralt dokument er utredningsinstruksen. Utredningsinstruksen er en felles instruks for departementene og de underliggende virksomhetene i statsforvaltningen. Formålet med instruksen er å framskaffe et godt grunnlag for beslutninger om statlige tiltak. I utredningsinstruksen står det at lovforslag og forskrifter skal utformes med utgangspunkt i Justis- og beredskapsdepartementets veileder Lovteknikk og lovforberedelse (2000). Denne veilederen dreier seg primært om lovteknikk, men den inneholder også noen generelle anbefalinger om språkføring.

I 2019 lanserte den norske regjeringen sin digitaliseringsstrategi, som inneholder et eget kapittel om klart og digitaliseringsvennlig regelverk. Her står det blant annet:

Regelverket bør være klart og forståelig, uten unødvendige skjønnsbestemmelser og med harmoniserte begreper. [...] Det er behov for å definere prinsipper og kjennetegn for et digitaliseringsvennlig regelverk. Dette arbeidet må også ses i sammenheng med arbeidet for klart lovspråk og innovasjon i offentlig sektor. 
Videre står det at regjeringen vil utarbeide en veileder for digitaliseringsvennlig regelverk og klart lovspråk. Digitaliseringsdirektoratet (Difis arvtaker) har fått i oppdrag å lage denne veilederen.

Uavhengig av Digitaliseringsdirektoratets planlagte veileder har Språkrådet lenge arbeidet med å utforme konkrete, eksempelbaserte og sjangertilpassede råd for lovskrivere. Resultatet av dette arbeidet er vår veileder Godt språk $i$ regelverk, som ble ferdig i 2021. Den er ment å være et praktisk verktøy som kan brukes i skrivearbeidet, og den kan forhåpentlig bidra til å heve kvaliteten på språket i regelverk. En kortversjon av veilederen er publisert på nettstedet klarspråk.no, fellesportalen for klart språk i offentlig sektor i Norge. Nettstedet klarspråk.no inneholder for øvrig både generelle skriveråd og informasjon om språkarbeid. I 2020 ble nettstedet fullstendig revidert og oppdatert med nytt innhold, blant annet mye informasjon om språk i lover og forskrifter. Dessuten inneholder nettstedet en samling eksempeltekster som kan være til hjelp for norske kommuner som ønsker å forbedre språket i tekstene sine.

\section{Språklige krav i to viktige lovforslag}

I 2019 ble det lagt fram to viktige lovforslag som kan få konsekvenser også for språk i regelverk: forslag til språklov og forslag til ny forvaltningslov.

Norge har tidligere ikke hatt noen egen språklov. Vi har bare hatt lov om målbruk i offentlig tjeneste (målloven), som regulerer bruken av de to norske skriftspråkene - bokmål og nynorsk - i offentlig sektor. Denne loven skal nå innarbeides i den nye felles språkloven, som blant annet stadfester offentlige organers ansvar for å bruke, utvikle og styrke de to norske skriftspråkene, samiske språk og nasjonale minoritetsspråk i Norge. I forslaget til språklov slås det fast at norsk er hovedspråket i Norge. Lovforslaget inneholder også en egen klarspråksparagraf:

\section{$\S 9$ Klart språk}

Offentlege organ skal kommunisere på eit klart og korrekt språk som er tilpassa målgruppa.

Forslaget til språklov ble behandlet i Stortinget våren 2021.

I forslaget til ny forvaltningslov slås det fast i paragraf 8 første ledd at forvaltningsspråket i Norge er norsk. Paragrafens andre ledd lyder slik:

Forvaltningsorganet skal bruke et språk som er klart, presist og så vidt mulig tilpasset mottakeren.

Det er et viktig signal at plikten til å skrive klart og forståelig er nedfelt nettopp i forvaltningsloven, som er en helt sentral lov for offentlig sektor. Forslaget til ny forvaltningslov har vært på høring og er nå til behandling $\mathrm{i}$ Justis- og beredskapsdepartementet. I høringsnotatet heter det (min utheving): 


\begin{abstract}
Det overordnete kravet er i alle tilfeller at forvaltningen skal bruke korrekt, klart og moderne språk, og det bør også være et mål å formulere seg så enkelt og lettfattelig som mulig. Disse språklige kravene har gyldighet både når forvaltningen yter veiledning, driver utredning, treffer og begrunner enkeltvedtak, utformer forskrifter og annet regelverk og i forvaltningens virksomhet ellers.
\end{abstract}

Et klarere språk i regelverket ellers vil hjelpe forvaltningsorganene å oppfylle kravene i den nye forvaltningsloven. Derfor bør det stilles krav til språk i regelverk.

\title{
Veien videre
}

Som nevnt blir krav om klart språk tatt inn i mandatet til stadig flere lovutvalg, og det er svært positivt. Men språklige krav i et lovutvalgs mandat er dessverre ingen garanti for at språket blir prioritert i praksis. Hvordan kan vi da sikre at lovspråket blir godt og klart?

Lover og forskrifter er tekster som skal leve lenge. De bør ha oversiktlig struktur og godt språk. Språkfaglig eksperthjelp og gode verktøy kan hjelpe lovskrivere i arbeidet med tekstene.

Språkrådet kan tilby slik eksperthjelp, og vi har laget verktøy, nærmere bestemt den nevnte veilederen Godt språk $i$ regelverk. Men det er frivillig å følge våre råd og bruke våre verktøy. Derfor trengs det noe mer forpliktende.

For det første: Et krav om språklig kvalitetssikring av viktige lover som angår mange, bør tas inn i sentrale styringsdokumenter, først og fremst den nevnte utredningsinstruksen. For det andre: Hvis et krav om språklig kvalitetssikring blir tatt inn i utredningsinstruksen, må statsforvaltningen settes $\mathrm{i}$ stand til å oppfylle kravet. Vi trenger en fast og formalisert ordning for obligatorisk kvalitetssikring av regelverk. Ordningen må omfatte kvalitetssikring av både struktur og språk, og den må bygge på den etter hvert velprøvde tverrfaglige arbeidsmetoden (skriveverksted).

Det er viktig at ordningen for språklig kvalitetssikring kommer inn et sted i saksbehandlingskjeden for utkast til nye lover. Ordningen må være så forpliktende at det skal svært gode grunner til for å fravike kravet om språklig kvalitetssikring. Dessuten må det settes av tilstrekkelig tid til kvalitetssikringen.

Etablering av en fast kvalitetssikringsordning forutsetter et stabilt fagmiljø som har nok ressurser til å dekke behovet. Språkrådet alene kan ikke etablere en slik ordning, men vi ønsker å være en del av den, og vi har gjentatte ganger påpekt at den trengs. Ordningen kan være noe tilsvarende det svenske Granskningskansliet - en fast gruppe med fagpersoner som arbeider for å sikre språklig og juridisk kvalitet i lovgivning.

I budsjettproposisjonen for 2021 skriver Kommunal- og moderniseringsdepartementet: 
Regjeringen arbeider med å stille mer tydelige krav til forvaltningen og med å sette arbeidet med klart lovspråk i system.

Skal et slikt arbeid settes i system, må det følge ressurser med. Foreløpig er det ikke satt av egne budsjettmidler til arbeidet med klart lovspråk, men det er lov å håpe.

\section{Kilder}

Barne- og familiedepartementet (2018), Utvalgsmandat til arbeidet med ny barnelov. https://www.regjeringen.no/contentassets/a02fb0c0772b48178 32ce409f04eaf7c/barnelovutvalg---mandat.pdf.

Difi (2013), Kan lovspråk temmes? En undersøkelse om klart språk $i$ lover og forskrifter, Difi-rapport 2013:1. https://www.sprakradet.no/upload/Klar spr\%C3\%A5k/Dokumenter/difi-rapport-2013-1-kan-lovspraaktemmes.pdf.

Difi (2015), Erfaringer fra lovspråkarbeidet 2014 (Questback-undersøkelse).

Difi (2016a), Råd og tips til dere som skal arrangere skriveverksteder - en arbeidsmetode som setter tverrfaglig samarbeid $i$ system. https://www. sprakradet.no/globalassets/klarsprak/dokumenter-og-presentasjoner/vareegne-sjekklister-og-rad/rad-og-tips-om-skriveverksteder.pdf.

Difi (2016b), Klart språk gir resultater. 10 eksempler fra stat og kommune. http://www.sprakradet.no/globalassets/klarsprak/dokumenter-ogpresentasjoner/andres-artikler-oppg-kartl/klart-sprak-gir-resultater.pdf

Difi (2017), Lovspråkundersøkelse i departementene. https://www.sprakradet.no/ globalassets/klarsprak/dokumenter-og-presentasjoner/undersokelser/ rapportdifi_klart-lovsprak_kvalitativ-del-0022.pdf.

Difi (2017), Erfaringer fra lovspråkarbeidet 2016 (Questback-undersøkelse).

Finansdepartementet (2016), Instruks om utredning av statlige tiltak (utredningsinstruksen). https://www.regjeringen.no/no/dokumenter/instruks-om-ut redning-av-statlige-tiltak-utredningsinstruksen/id2476518/.

Justis- og beredskapsdepartementet (2000), Lovteknikk og lovforberedelse. Veiledning om lov- og forskriftsarbeid. https:/www.regjeringen.no/ globalassets/upload/kilde/jd/bro/2000/0003/ddd/pdfv/108138lovteknikkboka.pdf.

Justis- og beredskapsdepartementet (2014), Utvalgsmandat til arbeidet med ny straffeprosesslov. https://www.regjeringen.no/globalassets/upload/jd/ved legg/mandat_utvalg_straffeprosesslov.pdf.

Justis- og beredskapsdepartementet (2015), Mandat for et lovutvalg til å revidere forvaltningsloven. https://www.regjeringen.no/contentassets/942a5fc1c6 214f728015e3dc20cd3870/mandat_lovutvalg_forvaltningsloven.pdf.

Justis- og beredskapsdepartementet (2019), NOU 2019: 5 Ny forvaltningslovLov om saksbehandlingen $i$ offentlig forvaltning (forvaltningsloven). https://www.regjeringen.no/no/dokumenter/nou-2019-5/id2632006/.

klarspråk.no (2020), Skriveverksted. https://www.sprakradet.no/klarsprak/ arbeidsmetoder/skriveverksted/. 
Kommunal- og moderniseringsdepartementet (2019), En digital offentlig sektor. Digitaliseringsstrategi for offentlig sektor 2019-2025. https://www. regjeringen.no/no/dokumenter/en-digital-offentlig-sektor/id2653874/.

Kommunal- og moderniseringsdepartementet (2020), Prop. 1 S (2020-2021) FOR BUDSJETTARET 2021. https://www.regjeringen.no/no/dokumen ter/prop.-1-s-20202021/id2768453/.

Kulturdepartementet (2020), Prop. 108 L (2019-2020) Lov om språk (språklova). https://www.regjeringen.no/no/dokumenter/prop.-108-1-20192020/id270 $1451 /$.

Kunnskapsdepartementet (2017), Mandat for offentlig lovutvalg på grunnopplaeringens område. https:/www.opplaringslovutvalget.no/man dat/.

Kunnskapsdepartementet (2018), Mandat for offentlig utvalg som skal gjennomgå regelverket for universiteter og høyskoler. https://www. univer sitetsoghoyskolelovutvalget.no/mandat/.

Opinion AS for Difi (2015a), «Klart lovspråk» - en kartlegging av hvordan forslag til ny forsvarslov virker $i$ praksis. http://www.sprakradet.no/ globalassets/klarsprak/juridisk-sprak/brukertesting_fdrapport forsvarsloven.pdf.

Opinion AS for Difi (2015b), «Klart lovspråk» - en kartlegging av hvordan forslag til ny adopsjonslov virker $i$ praksis. http://www.sprakradet.no/ globalassets/klarsprak/juridisksprak/brukertesting_bld_rapport_adopsjon sloven.pdf.

Språkrådet (2020), Råd om skriving av lover og forskrifter. https://www.sprak radet.no/klarsprak/om-skriving/sprak-i-lover-og-forskrifter/skriverad/.

Språkrådet (2021), Godt språk i regelverk. https://www.sprakradet.no/global assets/klarsprak-ny/om-skriving/lover-og-forskrifter/skriverad-lover-ogforskrifter/godt-sprak-i-regelverk_nettutgave.pdf.

Universitetet i Oslo (2019), Klarspråk $i$ juridisk forskning og undervisning (presentasjon av prosjekt). https://www.jus.uio.no/forskning/prosjekter/ klarsprak/.

Vinje, Finn-Erik (1995), Lovlig språk: om språk i lover og annet regelverk. https:/www.nb.no/items/44eebc1 ee4449551e9bc84f2e9ac85d?page=0 \& searchText $=$. 